\title{
Individuals' situations in a church context. Why taking an eco-systemic approach is crucial for supporting a gender balanced church with healthy singleness, dating, marriage and youth.
}

\section{Annabel Clarke}

\section{Introduction}

Imagine that a family member or friend (in your personal life), or a counselling client (in your professional life) wants to talk to you. Their situation is one of the following:

- a single person who feels isolated in a family-focused church;

- a single Christian man who would like to get married but cannot seem to commit to a relationship;

- a single Christian woman who would like to get married and have children but cannot seem to find suitable men to date;

- a Christian couple who are struggling in their marriage;

- a Christian man who feels he does not really 'fit in' at church;

- a Christian woman who is married to a man who does not share her faith;

- a Christian teenager who is struggling because their parents have split up, and they are no longer sure that good marriages are possible.

How do you respond? This may vary depending on a number of factors, including how much you are aware of the potential impact of the current church context.

This paper outlines the work of The Engage Network and why it is needed. Aspects of the current church context that affect the experiences of people such as those described above are then explored, and why an eco-systemic and solution-focused approach to helping them is so important. Finally, some practical points and next steps are suggested for both counsellors and clients.

You may find that some of what is covered is directly relevant to your own personal life too. If you are involved in church leadership at local or national level, you will also notice applications to your role there.

\section{Background}

To begin with, this paper will summarise what Engage is, and why it is needed.

\section{Why?}

Some years ago, I found a page of data on the internet, which showed that there were nearly twice as many women as men in the Church. The ratio really struck me, as did the implications for men, women and children, and the future of Christian families. The current balance is two men for every three women overall (Clarke, 2018, p. 54), and there are twice as many single women as single 
men in the majority of the Church (YouGov, 2014). In two generations' time, only $16 \%$ of today's church's grandchildren will have two Christian parents, if current trends continue (Clarke, 2018, p.19). The Church gender imbalance is therefore a crisis that has major consequences for all Christians, as will be shown throughout this paper.

\section{What?}

For several years after finding the page of data, I started to hear about ministries that seemed relevant to the situation, but who were not necessarily working together on these issues. They included ministries around men, singleness, dating, marriage, young people, and others. After a series of surprising 'coincidences', Engage was formed. This is a collaboration of national Christian organisations and individuals with the joint vision: 'For singleness or marriage to be a genuine choice, for all Christian women and men, through a Church which is gender balanced, and teaches about healthy singleness, dating and marriage.'

\section{Who?}

Engage brings together leading organisations including Christian Vision for Men, Care for the Family, Ridley Hall Theological College, Single Friendly Church, Youth for Christ, New Wine, Jesus House, the World Prayer Centre, and others. It involves individual Christians, those working at local and national church levels, and professionals in various diverse fields.

\section{How?}

Engage has a resource website (www.engage-mcmp.org.uk) and has produced a resource handbook, 7 Reasons Your Church Needs More Men: How to Lead a Gender balanced Church Supporting Healthy Singleness, Dating, Marriage and Youth (Clarke \& Blackaby, 2018). We facilitate joint work between different partners, which ranges from research projects to connecting speakers for national events. We hold conferences/webinars, teach sessions at theological training colleges and are also often promoting the excellent work that other people are doing.

\section{Key underlying principles of Engage}

We are keen for what we do to be biblical and research based.

The Great Commission is central. Jesus said, 'Go and make disciples of all nations, baptising them in the name of the Father and of the Son and of the Holy Spirit, and teaching them to obey everything I have commanded you' (Matthew 28:19-20). Engage is about people having the opportunity to hear and respond to the gospel and experience effective discipleship. Relationship with Jesus, spiritual and emotional flourishing and relationships of all kinds are fundamental discipleship issues for everyone.

Importantly, the Bible values both singleness and marriage. Single people are equally as valuable and competent as married people. At the same time, God's design from the start has been for marriage to reflect His covenant relationship with the Church, to be foundational to society, and to be personally experienced by most people. Engage is about 'making Christian marriage possible' (not compulsory!). By this, we mean marriage between Christians. Because the context of the church gender imbalance is core to our work, our focus is on relationships between men and 
women, including making it possible for a single Christian woman to marry a single Christian man, making it possible for any emotional barriers to marriage to be resolved, making it possible for a non-Christian spouse to come to faith, making it possible for marriages to be all they can potentially be when God is at their centre, and making it possible for the church's children to marry a Christian when they grow up. In the context of Engage, we use the phrase 'gender balanced' to mean an equal number of men and women.

Engage is about working together so that everyone benefits, and about men and women equally supporting each other. It involves organisations and churches collaborating because we see the overall 'big picture'.

\section{Context and balance}

It is essential that we all understand the context around issues that men, women, and young people face around singleness, dating and marriage. This includes wider socio-cultural trends and key relevant contexts within the Church.

\section{Socio-cultural trends}

The general socio-cultural context around relationships in the UK has changed significantly in recent decades, as Harry Benson (Research Director at Marriage Foundation) helpfully summarises in his chapter of 7 Reasons Your Church Needs More Men.

Among adults in their early thirties, $74 \%$ of women and $68 \%$ of men already live with a partner. Two thirds of these couples are married. Of the remainder who live alone, most have not married, leaving $21 \%$ of women and $30 \%$ of men are still single, unattached, and never married. By the time adults are in their late forties, $81 \%$ of women and $76 \%$ of men have been married and just $13 \%$ of women and $12 \%$ of men live alone, not co-habiting and not yet married (Benson, 2018).

The divorce rate is about 40\%; for married couples with children, the rate is $24 \%$. The break-up rate of parents who do not marry is 69\% (Benson, 2013, February). A report published in early 2017 by the Social Trends Institute (a US think tank) found that Britain has the highest rate of family instability in the entire developed world (DeRose, Lyons-Amos \& Huarcaya, 2017). Just under half of all British teenagers are not living with both biological parents (Benson, 2013, May).

Overall, there is less expectation from general society that people will get married - more couples cohabit now (Benson, 2018), but this is not so common among Christians. Many people have experienced their parents splitting up and avoid marriage themselves because they are afraid of being hurt, of failing, or of repeating their parents' mistakes. 'FOMO' can affect some if they commit to one person (Fear Of Missing Out - a very prevalent modern phenomenon) and unresolved emotional issues around relationships can lead to protracted singleness for others (e.g., previous rejection or hurt, unrealistic expectations of others). Christians are not immune to the impact of these trends, and we need to view Church data in the context of what is happening in wider society.

\section{Theological context}

It is beyond the scope of this paper or Engage to cover the theology of singleness and marriage in depth. However, a few central points are noted here. 
The concept of the 'gift of singleness' is often talked about in churches. This is taken from 1 Corinthians 7 where Paul explains that marriage is not mandatory (counter-cultural for many at the time), especially in the 'present crisis' (v26) of the Corinthians' then difficult situation. He talks about singleness and marriage and says 'each man [sic] has his own gift from God: one has this gift, another has that'. It is obviously important for single people to make the most of the positive aspects of their situation, and 'life live to the full' (John 10:10). However, there is often a 'spiritual re-framing' (whether uninformed or unintentional) of the unprecedented rate of unwanted singleness in our present-day Church, which is simply often deemed a 'God-given gift' for individuals, without acknowledgement of the impact of the gender imbalance or other societal influences.

Spiritual gifts are described in various Bible passages (e.g., Romans 12:6-8, 1 Corinthians 12:8-10 and 28-31, Ephesians 4:11-13 and 1 Peter 4:9-11), which tell us that the purpose of these gifts is to build up and strength the health of the body of Christ (the Church), to prepare us for works of service, and for the praise of God. Certainly, some people may feel they have a gift of singleness or a particular calling to be single and the Church must support them, but this is completely different from enforced singleness, which affects so many Christian women who stay single and childless due to the Church gender imbalance.

With regards to marriage, most Christians would agree that it is a covenantal sign of the relationship between God and His Church, and fundamental to God's design for society. Most would say that it is best for a Christian to marry another Christian, based on biblical teaching (e.g., 1 Corinthians 7.39; 2 Corinthians 6:14), and the experience that having a Christian spouse is a significant factor for a happy marriage whereas difficulties can arise in 'mixed' marriages (Evangelical Alliance, 2012) because the underlying spiritual vision is inevitably disparate if only one person believes. It is important to recognise that people may come to faith after they are married, and that there can be aspects in Christian, 'mixed' and non-Christian marriages that are 'good' or 'struggling'. Modern research also tells us that most single Christians want to marry another Christian (Pullinger, 2014).

Rev Dr Adrian Chatfield (Fellow, Ridley Hall Theological College, Cambridge) draws attention to the theological implications of today's context in his chapter of 7 Reasons Your Church Needs More Men.

... the work of Engage... is so crucial to the wellbeing of the church and the mission of God's kingdom today... the troubling gender imbalance in the church means that even where there is a will to foster and nurture healthy Christian marriages, it is plainly not possible for many Christian women... a failure in the area of Christian marriage is not just a failure of pastoral care or of social wellbeing. It contains the seeds of a theological failure, and obscures key aspects of God's nature and purposes in this world (Chatfield, 2018).

\section{The Church gender imbalance}

The current Church gender imbalance has vital consequences for the whole Church, which impact on many people's spiritual, emotional, relational wellbeing.

What is the gender imbalance, and its causes? 
As noted above, the overall ratio in the UK Church is two men to every three women. The numbers vary between studies, but studies show there are between $1 / 2$ million and $2 \frac{1}{2}$ million more women (e.g., Clarke, 2018, p55). The majority of the Church (62\%) is middle class, and among the single/unpartnered people in this group, the number of women is double that of men (YouGov, 2014).

Engage draws on research to help identify the main causes of these trends. Firstly, research shows that the majority of church ministers (84\% in 2017) are male (Brierley, 2017), and they get married and have children at a young age (Graveling \& Cara, 2017). This has three major consequences. Male ministers are less likely to understand how Church is experienced by non-Christian men, they do not share the personal experience of Christian women who are unable to get married and have children, and their limited understanding of the urgency of the issues impacts their motivation to address them.

Secondly, personality seems to be a factor. One study found that both men and women who scored more highly for more common 'male personality traits' were less likely to go to church, pray and have a positive attitude to Christianity. They preferred new and adventurous experiences, which the average church may not involve very often. Differences in religiosity were due to personality differences rather than being male or female (Penny, Francis \& Robbins, 2015). It has also been found that overall, clergymen have personality types closer to female population norms, and clergywomen personalities are closer to male population norms (Robbins, Francis \& Kay, 2001; Robbins, Littler \& Francis, 2001). Most church ministers are male, and they are probably going to most effectively engage with personalities similar to their own. A more personality-balanced leadership could help develop a more gender-balanced Church.

Thirdly, men often feel that they do not 'belong' in church. There are fewer single than married men in the UK Church. Research has found that if a man has children, they are more likely to attend church more often, and many appear to leave after ten years because of finding little of real value other than their presence for their children (YouGov, 2014). The gender imbalance also means there is a more limited group within which they can build deep friendship bonds.

Fourthly, it seems that social issues affecting men and boys are not always effectively addressed by the Church. When the Male Psychology Section of the British Psychological Society was being set up in 2018, it was demonstrated that there are a number of well-researched social and emotional problems that affect men and boys more than women and girls (e.g., suicide rates). There was a call for psychologists 'to pioneer new ways of reaching men and boys in need of our help and create the research, teaching and intervention that can help boys and men, and by extension also help the women and girls who share their lives' (Seager, Barry \& Liddon, 2018; p1213). From a spiritual perspective, this could describe part of Engage's work, and the Church is perhaps ideally placed to help further prevent and address the spiritual, emotional, and social issues underlying the problems that men are facing.

Finally, another UK survey showed that people also suggest the Church gender imbalance is due to romanticisation of the Church and its worship leading to more emotionalism, e.g., respondents noted that some song lyrics make it sound like Jesus is their boyfriend; the lack of masculine role models, lack of friendship patterns for men; and Church creating a sense of passivity (Pullinger, 2014). 


\section{Consequences for men}

Men are not currently being given equally effective opportunities as women to respond to the gospel and grow in faith. There is an urgent need for the Church to better reach and disciple more men, primarily for their own sake of course, but also for the health of the whole Church and wider society.

Fewer men in Church means fewer opportunities for them to support each other in life and growth, including in their singleness, dating and relationships, marriage, and parenting. For example, how often do Christian men intentionally disciple, support, and challenge other men about their relationships with women? It is important to note that the work of Engage focuses more on men and Church, because we want to address the impact of the Church gender imbalance. However, women's evangelism, discipleship and ministry are clearly equally important.

\section{Consequences for women}

Christian women do not currently have equal opportunity as Christian men to get married to someone who shares their faith and have children. If women (or men) are genuinely and honestly content with their singleness, then of course that is good. The Engage vision is about making singleness or marriage a genuine choice for all Christian women and men. However, currently, up to half of single Christian women face the dilemma of marrying a non-Christian, or remaining single and childless. This is hardly ever mentioned in churches. After a session which Engage ran for all the students at one theological college, a single female ordinand shared that 'It's excruciating - and no one ever talks about it.' Many women have to reconcile their suffering, resulting from faithful sacrifice, with a God who loves them. One respondent from the biggest ever national survey of single Christians highlighted that it had made them count the cost of following Christ more than any other single thing (Pullinger, 2014).

It is important that assumptions are not made about why a woman does not have children, or how they feel about their situation. Some women may not want children, and some may feel content about not having children, and it is important that this is acknowledged and understood. But for many, that is not the case. Most Christians are empathetic towards childless couples they know who would like a family. More prevalent, but much less recognised, however, is the situation of single Christian women who would like to have children but are not able to because they cannot find a suitable marriage partner.

Over the next two generations, this means the lives of several million babies being prevented, which makes the issue an intergenerational one.

Engage carried out a survey of more than 300 single Christian women over the age of 35 who do not have children (biological, fostered or adopted). When asked if they agreed that their church offers good pastoral support for single Christian women who are childless but would like a family, $65 \%$ strongly disagreed or disagreed, and $27 \%$ weren't sure. While some spoke about feeling 'OK' and noted the freedom that their situation could bring, most used negative descriptions, and nearly half (46\%) reported that they are dealing with grief and loss around not having children.

The main reason they gave for not having children was 'There aren't enough single Christian men in the Church.' They said that some of the least helpful things they had been told included 'It's 
God's will' and 'Just get a dog'. Some of the most helpful things included 'This must be hard and it's OK to grieve this. How can I help?' And 'We will keep on praying' (Clarke, 2018).

\section{Consequences for children and young people}

As noted above, if current trends continue, only about $16 \%$ of today's Church's grandchildren will have two Christian parents.

'Spiritual fatherlessness' is increasing due to the Church gender imbalance - both within families and within the Christian community. There are fewer children with a Christian father at home, and fewer positive male role models for them within the Church. This may impact on children and young people in many ways, including how they learn about their self-identity and healthy Christian relationships.

A report from Youth for Christ, Generation Z: Rethinking Culture, found the number one positive influencer for 11- to 18-year-olds was family (Youth for Christ, 2017). Although not all Christian marriages might be positive models, there is more potential for young people to learn about godly relationships if their parents are Christians, or they know other single and married people at their church.

It is, of course, also helpful for men and women of all ages to have 'older and wiser' spiritual fathers (and mothers) in their lives.

\section{Church teaching and discipleship}

Churches very rarely teach on healthy Christian singleness. They sometimes teach on marriage (e.g., marriage preparation/marriage courses), but usually only for people who have already found someone to marry, which is perhaps leaving it a bit late. They hardly ever teach on how to get from A (singleness) to B (marriage) in a godly way (i.e.,via dating and relationships). Each of these aspects of teaching, however, is vital.

\section{Church awareness and action}

Many Christians are unaware of the Church gender imbalance and its impact, and therefore there is a general lack of action. Even for those who are conscious of it, Engage has often heard church leaders say things like 'I know it's an issue, but what can be done?' Engage is helping to provide the practical answers.

If a church also teaches that Christians should marry another Christian but is doing nothing about the gender imbalance in their congregation (if there is one) and is doing nothing to support women in finding suitable marriage partners, then there is a significant disconnect between its words and actions.

\section{Balance}

Sometimes male ministers are worried about excluding or offending women. This is why some well-intentioned church leaders avoid 'doing men's ministry'. The salient message is probably 'balance' - women are unlikely to mind if the church further encourages men as long as it is very 
clear that the women are equally encouraged. If someone objects, then listening to their personal experiences and sharing the implications of the statistical realities may help.

Balanced teaching and discipleship are also required in churches, so there is equal support and input on singleness and dating and marriage and parenting.

While there are others that could be discussed, these are some of the important contexts of today's Church.

\section{An eco-systemic approach}

Systemic psychology has a wide range of applications, including for individuals, families, groups, and organisations.

Urie Bronfenbrenner was a developmental psychologist who saw the process of human development as being shaped by the interaction between an individual and their environment. He developed his 'ecological systems theory', which states that there are different levels of influence on a child. These are the 'microsystem' elements around the individual (e.g., family, peers, school, health services); the 'mesosystem' (the interactions between the microsystems); the 'exosystem' (links between social settings that do not involve, but can impact on the child), the 'macrosystem' (attitudes and ideologies of the culture or nation), and the 'chronosystem' (the impact of events and transitions over the life course, as well as changing socio-historical circumstances). This work has become foundational to how many psychologists now examine an individual's functioning and interaction with their environments (Bronfenbrenner, 2005).

When exploring how individuals experience church, singleness, dating, marriage or parenting, we need to take this sort of meta-perspective. Engage uses an eco-systemic interactionist model to illustrate how all the elements of our work are related (shown in Figure 1).

We are all surrounded by the current socio-cultural context around relationships, then within that is the Church and its gender imbalance, and within that is everything happening around marriage, parenting, youthwork, singleness, dating and relationships. (This is not to suggest that everyone should 'go round the circles' of life stages in the centre of the diagram.)

Engage intentionally gathers people from diverse ministry fields (including those represented in the diagram) that have traditionally been quite separate (e.g., men's ministry and youth work), showing how their work is a crucial, inter-linked part of the whole system. We promote mutual understanding and collaborative work at a national level, and within local churches. 


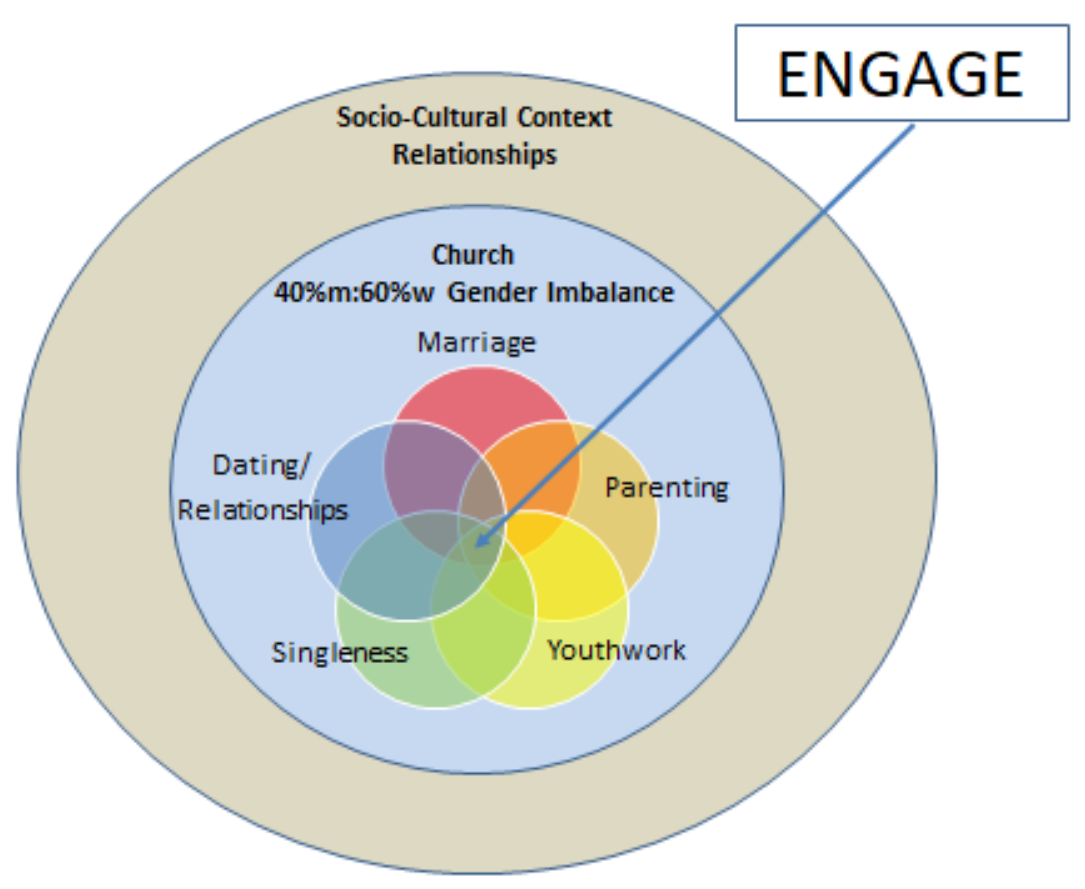

Figure 1 Engage eco-systemic interactionist model

\section{A solution-focused approach}

Solution-focused psychology, pioneered by Steve de Shazer and Insoo Kim Berg in the 1980s (De Jong \& Berg, 2008), also has a wide range of applications, including for individuals, families, groups and organisations. The work of Engage intentionally uses solution-focused approaches to generate positive steps to help individuals and the Church move forward on the issues we are addressing.

Traditionally, solution-focused psychology has worked on future possibilities rather than on problem causes, however Engage takes the approach of raising awareness of both perspectives, but then very much emphasising and promoting positive action.

The Church needs to articulate a clear vision of what healthy Christian singleness, dating and relationships and marriage can involve. Christians need to speak this out, live it, and model it to the next generation and the rest of society as a witness to God's grace and love.

Engage set up a series of consultation events for relevant UK experts. We used a structured systemic framework to co-create a positive vision of what things could look like if they were working well in the Church, in each of the ministry areas involved in Engage. If the Church can clearly articulate where it wants to get to, it is more likely to get there. The resulting series of 'consultation vision grids' form the basis of relevant chapters in our handbook, and other aspects of our work. 


\section{Issues and solutions}

The Engage resource handbook 7 Reasons Your Church Needs More Men looks in parallel at issues and solutions relating to the individual, the local church, and the national Church. This is because we need to understand the interaction between these three further systemic levels. Many positive practical suggestions are given in the book's vision grids at each of these levels.

For the purposes of this paper, the focus in the following section is on individuals. There are many deep psychological issues that counsellors may need to explore in therapy with clients, but these are not covered here. What follows is an outline of some context consequences that affect the life situations of individuals in the Church, so that both these, and the deeper issues can be held and explored together.

\section{Men's ministry}

Men can often lack a sense of belonging in a church. Organisations such as Christian Vision for Men (CVM) exist to support the Church to reach and disciple men. CVM has many resources and events to support individual men to grow in faith and relationships, and to support churches to include them.

When things are working well, men regularly meet with a small group of other men, with close, safe, trusting relationships that provide encouragement, challenge, and accountability. They are involved in pursuing Jesus wholeheartedly and are free from destructive behaviours and addictions (e.g., porn/alcohol/anger/others). They are aware of their main strengths, gifts, calling/purpose and are using these, both within and outside of their church. They are involved in reaching other men too and sharing their life and faith with them.

Readers wishing to further explore the field of male psychology may refer to The Palgrave Handbook of Male Psychology and Mental Health (Barry, Seager \& Sullivan, 2019).

\section{Singleness}

A third of church-going adults are single, many report that they feel isolated in their church, and most want to marry another Christian (Pullinger, 2014). They often report that churches are too 'family focused' (e.g., language used, sermon illustrations) and do not understand the issues they are facing. Main challenges include loneliness (even if they have good friends, it is often exhausting for single people to constantly be proactive and arrange social contacts and events), lack of male friends, childlessness, ill-health, housing and finance. Weekends, holidays (who to go with?) and birthdays (another year and nothing has changed?) can be painful - it is not unusual for these to be the dreaded times of the year.

When things are working well, single people have some sort of encouraging small group or prayer partner with whom they can meet regularly and with whom they can be totally honest. They will be supported to work through spiritual, emotional and relational issues, including those to do with boundaries, relationships, and their parents' relationship. They will consider how they feel about singleness and why, and intentionally pursue personal growth in all areas, identifying and using their gifts. Where needed, they will have sensitive support from friends and others to process the grief of singleness and childlessness. They will feel fully integrated socially into their church's life. 
Too often, single people feel pressured to either entirely focus on healthy singleness, or entirely focus on finding a marriage partner. If a relationship is right for them, then they should be encouraged to balance the pursuit of both healthy singleness and healthy dating.

\section{Dating and relationships}

The dating and relationships context in the Church is hugely impacted by two fundamental factors: the gender imbalance and the lack of teaching. As a result, $54 \%$ of single Christian adults report that they have not dated for at least a year, or, it is many years since they last went on a date (Pullinger, 2014).

The Church gender imbalance has had a significant adverse effect on the psychosocial dynamics between single men and women. These can be invisible to most Christians who have not experienced them personally. Research has shown (Pullinger, 2014; Verbi, 2017) that a significant over-supply of women in the dating market results in a very low level of exclusive dating commitment from men, but relatively high level of emotional, and sometimes physical, intimacy given by women. Women are more than twice as likely to be asked on a date by a non-Christian, and men often perceive that they can achieve a 'super model' girlfriend who fits some very specific criteria. Men are passive, indecisive and play the large field without always sufficiently valuing or respecting women. There is competition between women for men. Older men pursue women 10 or 20 years younger. Women give up and date non-Christians.

As well as addressing the gender imbalance, the Church needs to provide more teaching and discipleship around healthy dating and relationships. Work by Engage has shown that this can most helpfully be structured into a three-part framework. Firstly, the 'Foundations', with a healthy balanced single life. Secondly, 'Dating' which is defined as 'getting to know someone with a view to seeing whether or not we want to be in a relationship'. And thirdly, 'Relationship' (a mutually exclusive, romantic one), which is defined as 'getting to know someone with a view to seeing whether or not we want to get engaged'. Often, these 'Dating' and 'Relationship' stages are conflated, which leads to too much pressure from the start. One of the Engage dating mottos is 'a coffee isn't a marriage proposal'. When things are working well, people know the steps to intentionally take at the beginning, middle and end of both dating and a relationship. These are given in detail in the Engage handbook, along with lots of other practical resources.

\section{Marriage}

For Christians, later problems can sometimes be averted if couples discuss and manage shared, realistic expectations of being engaged, and being married. When things are working well, engagement is a time to support each other's healthy self-identity and value each other's similarities and differences.

Christians will then both intentionally work at having God at the centre of their marriage and commit to personal and emotional growth. They will both be seeking to develop sacrificial giving and forgiving. They will protect time to invest in their relationship, but also be outward-looking and hospitable. A detailed relationship 'MOT' such as the inventories by organisations such as Prepare-Enrich can be helpful in finding ways forward. 
Research by Evangelical Alliance found that more women than men were married to a nonChristian. Over $90 \%$ of Christian couples expressed happiness with their marriage, while only $66 \%$ of those in a mixed marriage did so (Evangelical Alliance, 2012). It will be helpful for couples to deeply explore and understand each other's beliefs and values before getting married and consider the implications of a 'mixed marriage' if one is already a Christian. The Christian spouse may value meeting and praying with others who are in similar situations. Churches need to both support the Christian spouse and welcome the non-Christian spouse.

\section{Parenting and youth work}

There are an increasing number of useful resources available to help adults encourage different aspects of the spiritual, emotional and relational development of children and young people from a Christian perspective. The work of Engage focuses on supporting young people's dating and relationships.

Research by Youth for Christ found that $94 \%$ of young people were on social media every day (Youth for Christ, 2017). Relationships of all kinds are often formed online instead of in person. Their context also involves social media pressures, online porn, sexting, and TV programmes that illustrate relationships that are far from God's design. Despite this, another survey found that $72 \%$ of 14-17 years olds wanted relationship education to understand how to build lasting relationships, and $78 \%$ said they wanted to get married (Family Stability Network \& Centre for Social Justice, 2018).

Many teenagers have experienced their parents separating, including those in Christian marriages. They may need support to consider how this affects them and their feelings about relationships in the future.

Parents and youth workers need to have thorough understanding of biblical teaching on relationships and how it is applied to today's experiences. Laura Hancock (National Ministries Director, Youth for Christ) discusses in 7 Reasons Your Church Needs More Men how adults need to talk explicitly with young people about how to do relationships well. She writes, 'So often, we don't plan to make bad dating and relationship choices, we just don't plan not to. By talking about things in advance of actual situations arising we can give young people a better chance of making the right choices when they find themselves negotiating relationships on their own.' This includes discussion about boundaries, triggers for unhelpful thoughts or behaviour patterns, online dating, conflict and breaking up well (Hancock, 2018).

Parents can often feel ill-equipped to help their teenagers in these areas. Paula Pridham (Executive Director of Care for the Family) writes in 7 Reasons Your Church Needs More Men how parents can helpfully pray and have their own support network of other parents. They can focus on understanding the challenges their children face, and on listening and questioning rather than telling. They can model 'good' relationships, and the same time identify other significant adults who can be part of their child's life. They can also help young people find the support of Christian peers to support them in being countercultural (Pridham, 2018). 


\section{Next steps}

It is hoped that this paper gives an overview of essential context factors for readers to consider while supporting individuals who come to them for help, whether family members, friends or counselling clients. By taking an eco-systemic and solution focused approach to understanding issues that people are facing, we have a more wholistic framework within which to facilitate personal healing and growth. It is recommended that next steps would usefully include reflection and prayer on the issues that have been covered.

7 Reasons Your Church Needs More Men: How to have a gender balance church supporting healthy singleness, dating, marriage, and youth is relevant for counsellors and their clients in exploring ways forward in their situation. It is suggested that the handbook would be a very helpful addition to your resource bank (all proceeds go to the ministry, not the authors), as Sue Monckton-Rickett, Chair of the Association of Christian Counsellors has highlighted.

This book is brave enough to tackle may difficult but vital topics often ignored by the church... it is a call to rethink and embrace vital change, but it also includes practical suggestions on how to do so, making it an invaluable resource for individuals and churches (Monckton-Rickett, 2018).

In conclusion, let us each pray and play our part in making the Engage vision a reality: 'For singleness or marriage to be a genuine choice, for all Christian women and men, through a church which is gender balanced, and teaches about healthy singleness, dating and marriage.'

\section{References}

Barry J.A., Kingerlee R, Seager M.J. and Sullivan, L. (Eds.) (2019) The Palgrave Handbook of Male Psychology and Mental Health. London: Palgrave Macmillan

Benson, H. (2013, February) What is the divorce rate? Cambridge: Marriage Foundation.

Benson, H. (2013, May) The myth of "long-term stable relationships" outside marriage. Cambridge: Marriage Foundation.

Benson, H. (2018) The wider context: current marriage trends. In A. Clarke \& N. Blackaby (Eds.), 7 Reasons Your Church Needs More Men: How to lead a gender balanced church with healthy singleness, dating, marriage and youth. Cambridge: The Engage Network.

Brierley, P. (2017) UK Church Statistics No. 3: 2018 Edition. Tonbridge: ADBC Publishers.

Bronfenbrenner, U. (2005) Making Human Beings Human: Bioecological perspectives on human development. London: Sage.

Chatfield, A. (2018) Theological foundations. In A. Clarke \& N. Blackaby (Eds.), 7 Reasons Your Church Needs More Men: How to lead a gender balanced church with healthy singleness, dating, marriage and youth. Cambridge: The Engage Network. 
Clarke, A. \& Blackaby, N. (2018) 7 Reasons Your Church Needs More Men: How to lead a gender balanced church with healthy singleness, dating, marriage and youth. Cambridge: The Engage Network.

Clarke, A. (2018) How do single Christian women feel about not having children? Cambridge: The Engage Network. http://www.engage-mcmp.org.uk/book (accessed 23 August, 2021).

Clarke, A. (2018) 'Men and church: the 'What?' questions'. In A. Clarke \& N. Blackaby (Eds.), 7 Reasons Your Church Needs More Men: How to lead a gender balanced church with healthy singleness, dating, marriage and youth. Cambridge: The Engage Network.

Clarke, A. (2018) 'What is The Engage Network and why is it needed?' In A. Clarke \& N. Blackaby (Eds.), 7 Reasons Your Church Needs More Men: How to lead a gender balanced church with healthy singleness, dating, marriage and youth. Cambridge: The Engage Network.

DeRose, L., Lyons-Amos, M., Wilcox, W., \& Huarcaya, G. (2017) The cohabitation go-round: Cohabitation and family instability across the globe. New York: Social Trends Institute.

Evangelical Alliance (2012) How's the family?

https://www.eauk.org/church/resources/snapshot/upload/EA-FAMILY-REPORT-WEB.pdf (accessed 23 August, 2021).

Family Stability Network \& Centre for Social Justice (2018) Relationships and Sex Education. https://www.centreforsocialjustice.org.uk/wpcontent/uploads/2018/03/Survation Report Web.pdf

Graveling, L. \& Cara, O. (2017) Living Ministry Wave 1 Panel Survey. The Church of England.

Hancock, L. (2018) 'Youthwork and discipleship around young people's dating and relationships: what would it look like if things were working well in the church?' In A. Clarke \& N. Blackaby (Eds.), 7 Reasons Your Church Needs More Men: How to lead a gender balanced church with healthy singleness, dating, marriage and youth. Cambridge: The Engage Network.

Monckton-Rickett, S. (2018) 'Book commendation'. In A. Clarke \& N. Blackaby (Eds.), 7 Reasons Your Church Needs More Men: How to lead a gender balanced church with healthy singleness, dating, marriage and youth. Cambridge: The Engage Network.

Penny, G., Francis, L.J. \& Robbins, M. (2015) 'Why are women more religious than men? Testing the explanatory power of personality theory among undergraduate students in Wales'. Mental Health, Religion \& Culture, 18(6), pp. 492-502. Permanent Warwick Research Archive Portal URL: http://wrap.warwick.ac.uk/81722 (accessed August 23, 2021).

Peter, De Jong; Berg, Insoo Kim (2008) Interviewing for solutions. Belmont Brooks/Cole.

Prepare-Enrich. https://www.prepare-enrich.co.uk/

Pridham, P. (2018) 'Parenting around young people's dating and relationships: what would it look like if things were working well in the church?' In A. Clarke \& N. Blackaby (Eds.), 7 Reasons Your 
Church Needs More Men: How to lead a gender balanced church with healthy singleness, dating, marriage and youth. Cambridge: The Engage Network.

Pullinger, D.J. (2014) Singleness in the UK Church. https://www.singlefriendlychurch.com/whatdo-single-christians-say-about-church/data-files-for-download (accessed August 23, 2021)

Robbins, M., Francis, L. J. \& Kay, W. K. (2001) 'The personality characteristics of Methodist ministers: Feminine men and masculine women?' Journal for the Scientific Study of Religion, 40(1), pp. 123-128.

Robbins, M., Littler, K. \& Francis, L. J., (2001) 'The personality characteristics of Anglican clergymen and clergywomen: The search for sex differences.' Pastoral Psychology, 60(6), pp. 877.

Seager, M., Barry, J. \& Liddon, L. (2018) 'Pioneering new ways of reaching men and boys.' The Psychologist, June 2018 edition, pp. 12-13. The British Psychological Society.

Verbi, S. (2017) See https://www.premierchristianity.com/home/70-per-cent-of-single-womenwant-christian-men-to-man-up-and-ask-them-out/2416.article (accessed August 23, 2021).

YouGov (2014) Men practising Christian worship. Christian Vision for Men and Single Christians Ltd.

Youth for Christ (2017) Gen Z: Rethinking Culture. https://yfc.co.uk/rethinkingculture (accessed August 23, 2021)

\section{About the author}

Annabel Clarke BA (Hons), PGCE, MSc, C.Psychol., AFBPsS, HCPC Registered Psychologist, Chartered Psychologist, Associate Fellow of the British Psychological Society

Annabel is a Senior Specialist Educational Psychologist for a large Local Authority where her role includes providing training for adults, as well as supervision for doctoral trainee psychologists and clinical supervision for experienced psychologists. She has over 20 years' experience supporting children, young people, adults, families and organisations, at work and through ministry in local churches. She is Co-Founder and Co-Chair of Engage, facilitating collaboration between national Christian organisations and churches to help promote a gender balanced Church with healthy singleness, dating, marriage, parenting and youth.

www.engage-mcmp.org.uk

info@engage-mcmp.org.uk

Facebook: Engage.MCMP

Twitter: EngageMCMP

\section{Copyright}

Copyright 2021 Annabel Clark 